\title{
THE PATENTABILITY OF HUMAN BEINGS: THE EFFECT OF A PROPOSED EXCLUSION IN THE PATENTS ACT 1953
}

\author{
Alexandra MacBean ${ }^{*}$
}

The author critically examines the debate over whether "human beings" ought to be patentable. The article outlines the choices between excluding just the patenting of whole organisms or parts of organisms. After considering New Zealand, Canadian, and European Union Patent law, the author concludes that at very least New Zealand must statutorily prevent the patenting of whole organisms

\section{INTRODUCTION}

The Patents Act 1953 (the Act) is currently under review. According to a Ministry of Commerce Paper produced in 1999: ${ }^{1}$

[T] he Government wishes to consider the current provisions in respect to the patenting of life forms and the issue of whether and what type of life form inventions should be patentable, taking into account the Government's broader economic policy.

The focus of this essay is the reform of the Act with reference to a particular life form: Human beings. Specifically it will consider the option, recommended by the New Zealand Institute of Patent Attorneys (NZIPA) to the Royal Commission on Genetic Modification 2001, that section 17 of the Act be repealed and that a new provision be introduced excluding humans from patentability. ${ }^{2}$

* Submitted for the LLB(Hons) degree at Victoria University of Wellington.

1 Ministry of Commerce Patenting of Biotechnological Inventions: Discussion Paper (Wellington, 1999) 4.

2 New Zealand Institute of Patent Attorneys Patenting of Biotechnological Inventions (submission to Royal Commission on Genetic Modification, 2001) 3 [NZIPA]. 
The new provision, according to this recommendation, should be based on the equivalent section in the Australian Patents Act 1990. ${ }^{3}$ Section 18(2) of the Australian Act states: "Human beings, and the biological processes for their generation, are not patentable inventions".

Section 17 of the Act gives the Commissioner of Patents discretion to refuse a patent application on the grounds that it is contrary to morality. It should be repealed according to the NZIPA because: "The administration of the patents system is not the appropriate place for ad hoc moral decisions of such magnitude to be made". ${ }^{4}$

The argument put forward in this essay is that the term human being can be interpreted in two ways: Narrowly to refer only to a whole organism or broadly to encompass human biological material as well. Any analysis of a provision excluding the patenting of human beings must assess the consequences of adopting one of these interpretations in the light of recent developments in biotechnology.

Once this assessment has been made, the question can then be asked: To render human beings - however they are best defined - unpatentable, is it necessary to amend the Act to include a specific provision or is it adequate in its present form? If an amendment is necessary, the provision must be one which allows New Zealand to fulfil its international obligations and which conforms to overseas practice.

Finally, the precise formulation of the provision put forward by the NZIPA - and recommended to Government by the Royal Commission on Genetic Modification 2001 - is evaluated.

\section{RECENT DEVELOPMENTS IN BIOTECHNOLOGY}

Biotechnology or "the exploitation of biological processes for industrial and other purposes" 5 is not a new phenomenon, but recent developments in human molecular biology have led to a burgeoning of new biotech industries. The range of products to emerge from these industries has fuelled the debate on the patenting of humans.

\section{A The Science of Molecular Genetics}

Many of the techniques of modern biotechnology utilise the cellular function of molecules of deoxyribonucleic acid (DNA).

3 NZIPA, above, 10.

4 NZIPA, above, 3.

5 Della Thompson (ed) The Concise Oxford Dictionary of Current English (9 ed, Clarendon Press, Oxford, 1995) 129. 
Each DNA molecule is called a chromosome. Human beings receive a set of 23 chromosomes from each parent: two sex chromosomes (two Xs or an $\mathrm{X}$ and a $\mathrm{Y}$ ) and twenty two duplicates. A complete set of chromosomes reside in the nucleus of almost every cell type. 6

A DNA molecule comprises two strands, each with a backbone of deoxyribose phosphate units to which is attached one of four bases, adenine (A), cytosine (C), guanine $(\mathrm{G})$, and thymine $(\mathrm{T})$. The strands are held together in a double helix by hydrogen bonds that form between complementary pairs of bases, adenine always pairing with thymine, and cytosine with guanine. Triplets of bases along one of the strands code for one of the twenty amino acids used in protein structure; a sequence of triplets - a gene - coding for the synthesis of a particular protein in the cell. ${ }^{7}$

Proteins are essential to an organism. It is from proteins that cell and tissue structure, as well as enzymes for chemical reactions are made. ${ }^{8}$ The mechanism by which protein production takes place in the cell involves two steps. First, the two strands of the DNA molecule separate so that the coding strand is available to act as a template for the construction of a ribonucleic molecule (RNA). RNA is chemically related to DNA but instead of deoxyribose has ribose units, and instead of thymine has a base of uracil (u). This messenger RNA molecule separates from the DNA and - within a cell structure called the ribosome - attracts amino acids in a complementary sequence along its length, that sequence corresponding to the arrangement of bases along the original strand of DNA. Between genes are long sequences of DNA bases that do not code for anything. Furthermore, the genes themselves do not exist in a continuous sequence but have stretches or exons that do code for parts of the protein and other stretches or introns that do not. 9

One of the key results of the Human Genome Project was to discover that probably fewer than 30,000 protein-coding genes exist in the human genome although there are

6 Human Genome Project Information <http://www.ornl.gov/TechResources/HumanGenome/publicat/judges/judge.html> (last accessed 2 September 2001).

7 Philip W Grubb Patents for Chemicals, Pharmaceuticals and Biotechnology (Clarendon Press, Oxford, 1999) 230.

8 Human Genome Project Information <http://www.ornl.gov/hgmis/elsi/patents.html> (last accessed 2 September 2001).

9 Grubb, above, 230-231. 
hundreds of thousands of distinct proteins. ${ }^{10}$ By various means, a single gene can encode multiple proteins. ${ }^{11}$

At a DNA level, human beings are very much alike: more than 99.9 per cent similar according to recent estimates. ${ }^{12}$ Some variations in the DNA base sequence have no effect at all, but the rest accounts for many of the physical differences between individuals. Furthermore, a variation in a coding sequence - inherited from a parent, arising spontaneously, or in response to environmental factors - can disrupt the manufacturing of proteins and cause disease or at least increase the risk of disease developing. ${ }^{13}$

A small percentage of disorders are caused by changes occurring in a single gene that is inherited from one or both parents: sickle cell anaemia or cystic fibrosis for instance. ${ }^{14}$ The causes of more common diseases such as heart disease, diabetes, and cancer are less easy to identify. These so-called complex diseases appear to involve many genes interacting with other genes and with environmental factors. ${ }^{15}$ Scientists believe the answer to these diseases may lie in identifying commonly occurring single nucleotide polymorphisms (SNPs) or changes in a single base or nucleotide (A, T, C, or G) that occur about once every 1300 nucleotide bases along the genome. ${ }^{16}$ Certain patterns of SNPs, it is thought, may render an individual more susceptible to a disease and, furthermore, could influence their response to drugs and other therapies. ${ }^{17}$

\section{B The Technology}

Out of molecular genetics have developed many of the techniques and products of the new biotech industries.

\section{Recombinant DNA technology}

Recombinant DNA technology encompasses the techniques of research - such as genesplicing that uses enzymes to break and rejoin DNA molecules (to create recombinant

10 "Proteins more important than genes - researchers" (12 February 2001) Independent Newspapers Ltd <http:www.stuff.co.nz/inl/index/0,1008,643514a12,FF.html> (last accessed 20 February 2001).

11 Philip Cohen "High in Protein" (4 November 2000) New Scientist United Kingdom 38-39.

12 Kathryn Brown "Close Cousins" (4 November 2000) New Scientist United Kingdom 42.

13 Denise K Casey "Genes, Dreams, and Reality" (1999) 83 Judicature 105.

14 Casey, above.

15 Human Genome Project Information <http://www.ornl.gov/TechResources/HumanGenome/publicat/judges/judge.html> (last accessed 2 September 2001).

16 Kathryn Brown "Close Cousins" (4 November 2000) New Scientist United Kingdom 44.

17 Brown, above, 45. 
DNA) - and specific products such as DNA sequences, which may be whole genes or fragments of genes. ${ }^{18}$ Some fragments, called expressed sequence tags (ESTs), are pieces of laboratory-made versions of genes or DNA that contain only exon regions. ${ }^{19}$ Other products are proteins including insulin and human growth hormone, lymphokines, and blood clotting factors. ${ }^{20}$

The technology makes possible powerful diagnostic tools such as gene or DNA tests allowing doctors to scan a patient's DNA for variations in sequences of bases that prefigure the onset of disease. ${ }^{21}$ Already tests exist for Huntington's disease, cystic fibrosis, inherited breast and ovarian cancer, Tay-Sach's disease, and phenylketonuria, among others. One type of DNA test involves creating probes - short pieces of DNA sequences that will bind with a mutated sequence in the patient's sample. Another involves biochemical tests that screen for gene products such as enzymes and other proteins. ${ }^{22}$

Increased knowledge of genetic sequences and protein structure holds out the promise of better therapies: Of vastly more effective drugs with fewer side effects, ${ }^{23}$ for instance, and of gene transfer whereby defective genes are replaced or supplemented by others to treat or prevent disease - or to modify such traits as height, weight, stamina and even intelligence. $^{24}$ Such therapy can alter somatic (body) or germ (egg and sperm) cells. If somatic gene therapy takes place only that individual is affected. By contrast changes are passed on to offspring in germline gene therapy. ${ }^{25}$

Already the techniques of gene transfer are used to insert human genes into animals ("transgenics") such as sheep, goats, and cows so that they may be pharmed for the large quantities of human proteins they subsequently produce. Transgenics may also be used to model human diseases. ${ }^{26}$ Other developments include using animals such as pigs to grow

18 Philip W Grubb Patents for Chemicals, Pharmaceuticals and Biotechnology (Clarendon Press, Oxford, 1999) 233.

19 Grubb, above, 232.

20 Grubb, above, 234

21 Denise K Casey "Genes, Dreams, and Reality" (1999) 83 Judicature 105.

22 Human Genome Project Information <http://www.ornl.gov/TechResources/HumanGenome/publicat/judges/judge.html> (last accessed 2 September 2001).

23 Kathryn Brown "Close Cousins" (4 November 2000) New Scientist United Kingdom 45.

24 Casey, above.

25 Maxwell J Mehlman "Gene Therapy and Beyond" 199983 Judicature 124.

26 Casey, above. 
organs with human genes to render them more acceptable on transplantation to a host human being. This is xenotransplantation. ${ }^{27}$

In future, cloning of human material may allow the production of whole organs from single cells. In somatic cell nuclear transfer, genetic material from the nucleus of a body cell is injected into an egg cell from which the nucleus along with its genetic material has been removed. The cell divides as a human embryo develops. The remarkable feature of very young embryonic cells (or stem cells) is that they are non-specialised but eventually turn into every kind of tissue. This means that new tissue could be grown to replace diseased or damaged parts of the body, providing cures for Parkinson's, diabetes, Alzheimer's, and paralysis. Furthermore, organ rejection would be eliminated by using the patient's own body cells as adult specialised cells could be made to revert to an undifferentiated state. ${ }^{28}$ At present, the main source of embryonic stem cells is embryos not required by IVF clinics. Cloning embryos would provide an unlimited source of material for research. ${ }^{29}$

\section{Monoclonal Antibody technology}

Although some writers appear to equate biotechnology and its human applications with genetic engineering or recombinant DNA technology, others more accurately include monoclonal antibody technology. ${ }^{30}$ This technology relies on the working of the immune system. White blood cells originating as stem cells in the bone marrow differentiate into Blymphocytes and T-lymphocytes. B-lymphocytes produce antibodies, proteins which bind themselves to foreign protein molecules or antigens rendering them inactive. ${ }^{31}$

Antibodies can be used therapeutically, to supplement an individual's immune system, but also as diagnostic and research tools. To date, some diagnostic techniques and a few commercially successful therapies have been developed using this technology. ${ }^{32}$

\section{PATENT LAW IN NEW ZEALAND}

No express reference to biotechnological inventions occurs in the Patents Act 1953, which is the primary source of patent law in New Zealand. Unsurprisingly, therefore, the

27 Casey, above.

28 Human Genome Project Information <http://www.ornl.gov/TechResources/HumanGenome/elsi/cloning.html> (last accessed 2 September 2001).

29 Nancy Gibbs "Baby It's You! And You, and You ..." (19 February 2001) TIME United States 44.

30 Philip W Grubb Patents for Chemicals, Pharmaceuticals and Biotechnology (Clarendon Press, Oxford, 1999) 238.

31 Grubb, above, 238-239.

32 Grubb, above, 242. 
Act neither expressly prohibits nor expressly allows that human beings fall within the range of patentable subject matter.

To be eligible for patent protection, the subject matter of a claim must be an invention, as defined by section 2 of the Act:

Invention means any manner of new manufacture the subject of letters patent and grant of privilege within section 6 of the Statute of Monopolies and any new method or process of testing applicable to the improvement or control of manufacture; and includes an alleged invention.

Section 10(7) of the Act provides that a claim cannot extend to a substance when found in nature. A grant may be opposed on grounds provided by section 21 of the Act including a lack of novelty (subsections (a) to (d)), obviousness, and a lack of an inventive step (subsection (e)). The invention must also be industrially applicable. ${ }^{33}$

\section{THE EFFECT OF A SPECIFIC PROVISION EXCLUDING HUMAN BEINGS FROM PATENTABILITY}

The Royal Commission on Genetic Modification acknowledges in its report that "[t]he debate on patenting living organisms also covers the identifying and characterising of particular biological molecules or genes". ${ }^{34}$ Therefore, in so far as the debate relates to human beings, it covers the patenting of human biological material (or to use the Royal Commission's phrase "human related matter"135), as well as human beings as whole organisms. This means that the effect of a specific exception excluding human beings from patentability depends on how the term human being is interpreted.

\section{A A Narrow Definition of "Human Being"}

1 Two Versions of a Narrow Definition

Irrefutably, the term "human being" refers at least to a human organism from birth onwards. This is the definition of "human being as organism" at its narrowest. Some would argue that the definition should be slightly wider and encompass the organism at an earlier stage of its development: At conception, or as an embryo or foetus. Proponents of either version of the narrow definition of human being would deny the term applies to human biological material.

33 Ministry of Commerce Reform of the Patents Act 1953: Proposed Recommendations (Wellington, 1992)

34 Royal Commission on Genetic Modification Report of the Royal Commission on Genetic Modification (Wellington, 2001) 282.

35 Royal Commission on Genetic Modification, above, 284. 
(a) Individual rewards and societal benefits

One of the strongest arguments in favour of a narrow definition relates to the purpose of patent law, which is often described in terms of a bargain struck between innovators and the public at large. ${ }^{36}$ In exchange for complete disclosure of information at the beginning of the patent term (20 years) innovators are granted exclusive rights to "make, use, exercise, and vend a manner of new manufacture in New Zealand". ${ }^{37}$ A patent system rewards those who invest their resources in research and development while it promotes public access to new information and technology. Patent protection means inventions are less likely to be retained as trade secrets, an exercise that can be both costly and difficult, and that may result in wasteful duplication of effort.

Benefits to society at large go beyond access to new technologies, according to this view. As the information store grows with new disclosures, further innovation takes place resulting in new jobs and industries and increasing economic growth. There is some evidence to suggest that the stronger a country's patent protection, the higher the level of its industrial development. ${ }^{38}$

If a definition of human being is adopted that restricts the meaning of the term to an organism at birth and beyond, then public access to the widest range of technologies is more likely to occur. A very narrow definition allows the patenting of biological material such as DNA sequences and thereby encourages the development of diagnostic and therapeutic techniques and products that use this material. Amongst the techniques promoted are DNA tests for inherited diseases such as cystic fibrosis and, perhaps, for complex diseases such as cancer and heart disease. Therapy by means of gene transfer techniques and the use of more effective drugs is encouraged, as is xenotransplantation and the pharming of transgenic animals for human proteins. The potential of monoclonal antibody technology is also more likely to be realised. Furthermore, with better treatments available, patients need fewer routine medical examinations and are less likely to be hospitalised for long periods. The burden on the health system is reduced considerably. ${ }^{39}$

36 Ministry of Commerce Reform of the Patents Act 1953: Proposed Recommendations (Wellington, 1992) 3.

37 Patents Regulations 1954, Third Schedule, Letters Patent.

38 Philip W Grubb Patents for Chemicals, Pharmaceuticals and Biotechnology (Clarendon Press, Oxford, 1999) 49.

39 Royal Commission on Genetic Modification Report of the Royal Commission on Genetic Modification (Wellington, 2001) 243. 
If the status of human being is achieved by an organism before birth, then research into embryonic stem cells is threatened, along with the development of techniques to provide replacement tissue for damaged or diseased body parts and cures for degenerative diseases such as Parkinson's and Alzheimer's.

(b) Moral concerns

The precise point at which an organism becomes a human being cannot be determined solely by reference to the quantity of economic or biomedical gains to be made. Moral concerns are also relevant. ${ }^{40}$ Restricting human being to its narrowest reference might be regarded as promoting the dignity of the human organism at least from birth onwards. However, the Roman Catholic Church teaches that conception marks the point at which a soul - and thereby a human being - is created. According to the United States Director of the National Conference of Catholic Bishops' Commission on Science and Human Values: "Each embryo is a human being simply by dint of its genetic makeup". ${ }^{41}$ A recent survey by New Zealand's Independent Biotechnology Council (IBAC) suggests this view is prevalent in the community at large. "People ... were almost universally opposed to the cloning of people", 42 the Chair of IBAC is reported as saying. It is interesting to note however, that this view is less strongly held when the potential benefits of research on stem cells are made apparent: "When it came to the cloning of embryos for use in stem cell research that had potential medical benefits ... people were less certain". ${ }^{4}$

(c) Statutory consistency

Defining a human being as an organism from birth onwards would achieve consistency with the only definition of the term in New Zealand statutory law. According to section 159(1) of the Crimes Act 1961, the status of human being is achieved when a child has completely proceeded in a living state from the body of its mother, whether it has breathed or not, whether it has independent circulation or not, and whether the navel cord is severed or not.

40 See Brian M Belcher and Geoffrey Hawtin A Patent on Life: Owners Tip of Plant and Animal Research (International Development Research Centre (Canada) Ottawa, 1991) 20, for a discussion on the ethics of patenting plants and animals.

41 Nancy Gibbs "Baby, it's You! And You, and You ...". (19 February 2001) TIME United States, 44.

42 Mark Revington "Life in New Zealand" (11 August 2001) The Listener New Zealand 22.

43 Revington, above. 


\section{B A Broad Definition of Human Being}

A provision excluding human beings from patentability may be also interpreted broadly to encompass human biological material including cells, genes and gene fragments, SNPs, and proteins, as well as human beings as entire organisms.

1 Arguments for a Broad Definition

(a) Patenting life

One of the most frequently articulated arguments in favour of adopting a broad interpretation assumes that a patent on human material grants property rights in a piece of nature. ${ }^{44}$ It imagines that patents will take away from people ownership of the body parts they are currently using such as sequences of DNA bases or proteins like insulin. Acting on this assumption - and to highlight a perceived invasion of privacy - a woman in Britain applied to patent her own DNA. ${ }^{45}$ Her assumption, it seems, is shared by many New Zealanders: "[A] common public concern about gene modification", the Royal Commission on Genetic Engineering noted after hearing numerous submissions, "relates to the legitimacy of 'owning life'". 46

The standard response to this concern is to state that it is based on a misapprehension of the scope of intellectual property rights: They do not extend to naturally occurring products or "laws of nature". ${ }^{47}$ This "product of nature" doctrine is enshrined in Section 10(7) of the Act and follows from the requirements of patentability - novelty, inventive step, utility, or manner of new manufacture. Accordingly, patents may be granted for isolated and purified DNA sequences as opposed to genes as they occur naturally on the chromosome. Mere discoveries are not patentable.

This argument forms part of the reasoning of the Supreme Court of California in Moore $v$ Regents of the University of California. ${ }^{48}$ In denying that the plaintiff had any claim to a cell-line and its products (which had been developed from his excised spleen cells and patented by researchers), it argued that the patented cell-line was "both factually and legally distinct from the cells taken from Moore's body". ${ }^{49}$ The researchers had isolated

44 Diana McCurdy "For Sale: Your Genes"(7 July 2001) The Dominion Wellington 3.

45 Andrew Brown "America Holds the Cards" (15 November 2000) The Guardian London.

46 Royal Commission on Genetic Modification Report of the Royal Commission on Genetic Modification (Wellington, 2001) 283.

47 See Royal Commission on Genetic Modification, above.

48 Moore $v$ Regents of the University of California (1990) 793 P 2d 479 (SCCal).

49 Moore, above, 492, Panelli J. 
Moore's T-lymphocytes and cloned a cell-line that overproduced lymphokines, a task generally regarded as difficult. It was "this inventive effort that patent law rewards, not the discovery of naturally occurring raw materials". ${ }^{50}$ The other reasons were based on the Court's finding that neither case law nor California statutory law suggested that a person retains sufficient interest in excised cells to support a cause of action for conversion when the cells are used for medical research. ${ }^{51}$ Furthermore, to expand conversion law would inhibit socially beneficial research. ${ }^{52}$

In his dissenting opinion, Justice Mosk determined that California statutory law did not extinguish all of a person's property rights in his or her excised cells ${ }^{53}$ and that, at the very least, Moore retained the right to use his cells for the same purposes as the defendants. ${ }^{54}$ Justice Mosk found a continuity existed between the naturally occurring product and the patented cell-line. In fact, he claimed, no physical distinction existed between Moore's cells and the cell line: The cell-line merely extended the life of the cells. ${ }^{55}$ Justice Mosk did not deny that the defendants had an interest in the cell-line - their ingenuity had been primarily responsible for its existence - but he also asserted that Moore had made a crucial contribution. ${ }^{56}$ "A patent", Justice Mosk concluded is "not a license to defraud". ${ }^{57}$ To achieve a just and equitable solution, he suggested, Moore might be regarded as a joint inventor. ${ }^{58}$

What Justice Mosk does, in effect, is to blur the distinction between a piece of nature and the subject-matter of a patent raising the question: Should the inventor's intellectual property rights extinguish whatever proprietary interest a donor retains in his or her body parts? It can be argued that this is a question that only appears reasonable when posed in a case like Moore $v$ Regents of the University of California where just one donor is involved and that typically the raw material of a genetic product is from multiple human sources. ${ }^{59}$

50 Moore, above, 493, Panelli J (emphasis added).

51 Moore, above, 489, Panelli J.

52 Moore, above, 494, Panelli J.

53 Moore, above, 509, Mosk J.

54 Moore, above, 510, Mosk J.

55 Moore, above, 511, Mosk J.

56 Moore, above.

57 Moore, above, 512, Mosk J.

58 Moore, above.

59 Brett J Trout "Patent Law - A Patient Seeks a Portion of the Biotechnological Patent Profits in Moore $v$ Regents of the University of California" (1992) 17 JCorpL 513, 531. 
In theory, however, this should make no difference to the question of ownership of the material, only to how much it is worth. If anyone's DNA will do, for example, then its market value might be correspondingly low.

(b) Devaluing human beings

A related argument in favour of adopting a broad definition suggests that extending patent eligibility threatens to devalue human life. It is based on the supposition that molecular structure - especially of the genome - determines what it is to be human. As Alex Mauron writes: ${ }^{60}$

With the complete human genome now at hand, the notion that our genome is synonymous with our humanness is gaining strength. This view is a kind of 'genomic metaphysics': the genome is viewed as the core of our nature, determining both our individuality and our species identity.

Yet this reductive approach to being human ignores other defining components of our identity such as culture. ${ }^{61}$ It also exaggerates the uniqueness of human beings at the genetic level. Research has shown that we share varying numbers of our genes with other organisms: on average a startling 85 per cent with mice and 98 per cent with apes. ${ }^{62}$

(c) Environmental concerns

One of the arguments for imposing a complete ban on the patenting of human biological material is that it promotes research that puts the environment at risk.

The current debate in New Zealand centres on the insertion of synthetic copies of human genes into animals such as cows to produce milk rich in a particular protein. Environmentalists fear that by crossing the species divide in this way, researchers are threatening the wellbeing of the whole planet. The ultimate consequences of this research are unknown, but could be perilous. ${ }^{63}$

The simplest way of refuting this argument is to assert that granting a patent does not authorise the patent holder to use the technology but merely to prevent others from doing so. Environmental considerations are best dealt with by such organisations as the

60 Alex Mauron "Is the Genome the Secular Equivalent of the Soul?" (2 February 2001) Science United States 831.

61 Alex Mauron, above.

62 Human Genome Project Information <http://www.ornl.giv/hgmis/faq/compgen.html> (last accessed 2 September 2001).

63 See Mark Revington "Life in New Zealand" (11 August 2001) The Listener New Zealand 22. 
Environmental Risk Management Authority (ERMA) operating within appropriate environmental legislation such as Hazardous Substances and New Organisms Act 1996.

(d) Impeding research

More powerful arguments arise when the practical effects of extending patents in this area are considered. Although, theoretically, a bargain exists at the heart of patent law it does not necessarily mean that public good will always flow from the granting of property rights.

Garrett Hardin, in describing one of the justifications for granting private property rights, metaphorically coined it the "tragedy of the commons". ${ }^{4}$ According to this theory, a resource held in common is susceptible to overuse because an individual gains no benefit by restricting his or her use of that resource while others cannot be excluded. "Freedom in a commons brings ruin to all", 65 wrote Hardin. It has been argued that, contrary to conventional wisdom, the privatisation of biomedical research could bring about a "tragedy of the anticommons": If multiple owners each have an exclusive right to a particular piece of a resource, no one can use it or, at least, not very effectively. ${ }^{66}$

In the area of genetics, Michael Heller and Rebecca Eisenberg have identified ways in which such a tragedy might occur. Two of their examples involve the patenting of results upstream in the research and development process, specifically the patenting of gene fragments for which no protein or biological function has been identified. They argue, any downstream product such as a therapeutic protein or a genetic diagnostic test is likely to incorporate more than one fragment, requiring a pharmaceutical company to engage in costly negotiations with multiple patent holders before accumulating sufficient licences to use that research effectively in developing a product. Costs will be driven even higher if patent holders overestimate the value of the fragment they own or if there is no substitute for a particular fragment. Costs will also be incurred in identifying the patents that apply. As costs increase and the outcome remains unsure, product development may be abandoned altogether. ${ }^{67}$

The second example arises when pharmaceutical companies attempt to test the efficacy of a new product by screening it against relevant biochemical receptors. If different companies own the receptors, the task of gathering licenses may be so arduous that

64 Garrett Hardin "Extensions of 'The Tragedy of the Commons'" (1 May 1998) Science United States 589.

65 Garrett Hardin, above.

66 Michael A Heller and Rebecca S Eisenberg "Can Patents Deter Innovation?" (1 May 1998) Science United States 698.

67 Heller and Eisenberg, above, 699. 
pharmaceutical companies may choose to develop less promising products or, instead of screening the product, conduct clinical tests that expose people to unnecessary risk. ${ }^{68}$

One response to this argument is to address the particular subject matter of the examples - gene fragments for which no function has been identified - and suggest that such material is unlikely to be patented because the utility requirement would not have been met. However, the strength of Heller and Eisenberg's argument is illustrated by the actual outcome of the patenting of two genes for which the function has been determined. Myriad Inc developed a technique to identify mutations in two genes that, if present in a woman, indicate an $80 \%$ chance of her developing breast cancer. They patented the technique and the genes known as BRAC1 and BRAC2. In the United States, this has given Myriad a monopoly over BRAC screening. ${ }^{69}$ In Britain and Europe, other screening methods that depend on identifying the genes but which are simpler and cheaper - or simply more effective in some cases ${ }^{70}$ - are under threat. If these methods are forced out of the market, a large proportion of the public will be deprived of the benefit of early diagnosis of breast cancer.

Another impediment to product development is patent stacking whereby a single DNA sequence can be patented as an EST, a gene, and a SNP. Using that sequence means paying licensing costs to all the patent owners, which might prove prohibitive. ${ }^{71}$

A "tragedy of the anticommons" is not the inevitable result of allowing human biological material to be patented but it does point to the need to consider seriously the effects of granting rights in inventions arising out of upstream research, such as gene fragments and SNPs.

\section{Summary}

In summary, there are strong arguments for both the narrow and broad interpretation of human being. The process of evaluating the strength of each position is complicated by the varying nature of the arguments. How, for example, can an estimate of economic growth be weighed against a concept of human identity deriving from moral beliefs? If conventional wisdom is right, however, and more biomedical gains are to be made by allowing patenting than by not, then the balance of the arguments swings in favour of a narrow interpretation of human being - if only because alleviating suffering is generally

68 Heller and Eisenberg, above.

69 James Meek "Money and the Meaning of Life" (17 January 2000) The Guardian United Kingdom.

70 Michael Balter "Transatlantic War Over BRAC1 Patent" (8 June 2001) Science United States 181.

71 Human Genome Project Information <http://www.ornl.gov/hgmis/elsi/patents.html> (last accessed 2 September 2001). 
regarded as a moral good. A provision that excludes human beings from patentability on this analysis should therefore refer to whole organisms at least from birth.

\section{$V \quad$ INADEQUACIES OF THE PATENTS ACT 1953 IF SECTION 17 IS REPEALED}

The question must next be asked: In order to exclude human beings as whole organisms from patentability is it necessary to amend the Act?

In its report, the Royal Commission on Genetic Modification (the Royal Commission) expresses the opinion that "under existing New Zealand legislation and practice it is unlikely that a patent covering human beings would be granted". ${ }^{72}$ A specific provision is "desirable" only "to put the issue beyond doubt". ${ }^{73}$ Section 17 , the morality section, is cited as the basis of the Patent Office's policy to refuse a patent application for humans. If section 17 is repealed, as recommended by the NZIPA, then the statutory basis for the Patent Office's policy will be swept aside on this analysis.

\section{A Product of Nature}

According to the Royal Commission, at least two other sections exist in the Act to prevent the patenting of a human: "[S]ections 2 and 10(7) prevent the patenting of a substance found in nature". ${ }^{74}$ The relevance of section 10(7) and of section 2 - as it is characterised by the Royal Commission - is not altogether clear. It is not human beings, as they are found in nature, that are at risk. It is human beings whose genomes have been modified by therapy or who been constructed in vitro.

\section{B "Manner of Manufacture"}

Nonetheless, there is an argument that it is not necessary to enact a specific provision even if section 17 is repealed because: ${ }^{75}$

[T]he Intellectual Property Office has a practice of excluding human beings from patentability on the basis that human beings cannot be regarded as a manner of manufacture and therefore do not fall within the definition of invention contained in the Patents Act.

The inadequacy of this argument is suggested by a decision of the Federal Court of Appeal in Canada and two cases heard before the New Zealand Court of Appeal.

72 Royal Commission on Genetic Modification Report of the Royal Commission on Genetic Modification (Wellington, 2001) 284

73 Royal Commission on Genetic Modification, above.

74 Royal Commission on Genetic Modification, above.

75 Ministry of Commerce Patenting of Biotechnological Inventions: Discussion Paper (Wellington, 1999) 14. 
In President and Fellows of Harvard College $v$ Canada (Commissioner of Patents), ${ }^{76}$ the Federal Court of Appeal in Canada considered the patentability of non-human mammals, specifically a transgenic mouse: Harvard University's "oncomouse".

Although Rothstein JA denied in the concluding - and obiter - statements of his judgment that the Court's decision in favour of the appellant did not have any implications for the patentability of humans ("clearly ... the Patent Act cannot be extended to cover human beings"77), it is arguable that his analysis of the issue could readily be used to extend Canada's Patent Act even further. As Mark Perry and Priti Krishna write: "Although the court pronounced on the oncomouse patent application, this decision goes much deeper. [It] open[s] the door to patent claims on other life-forms that have been genetically modified ... ". ${ }^{78}$ As it stands, the decision opens the door to claims on genetically modified human beings.

Rothstein JA's analysis rests on characterising the issue as one of pure statutory interpretation: "[A]ll that is at issue in this appeal is the interpretation of the Patent Act and the determination of whether, on the basis of the evidence, the appellant's product is patentable in accordance with that interpretation". ${ }^{79}$ Policy concerns, which might prompt a distinction being made between lower and higher life forms, are not matters for the courts, such questions being better addressed by Parliament. ${ }^{80}$

A proper interpretation of the Patent Act will take account of its object, which is "to promote the development of inventions in a manner that benefits both the inventor and the public". ${ }^{81}$ The Act does not expressly provide for "the type of claims at issue here", that is to say, "new life form[s]"82 nor for biotechnological inventions generally. Consequently, (following previous observations of the Supreme Court of Canada) new life forms will only constitute patentable subject matter if they meet the traditional requirements for a patent. 83

76 President and Fellows of Harvard College $v$ Canada (Commissioner of Patents) [2000] CA 98.

77 President and Fellows of Harvard College, above, para 207.

78 Mark Perry and Priti Krishna "Making Sense of Mouse Tales" (2001) 23 EIPR 196.

79 President and Fellows of Harvard College, above, para 110.

80 President and Fellows of Harvard College, above.

81 President and Fellows of Harvard College, above, para 106.

82 President and Fellows of Harvard College, above, para 111.

83 President and Fellows of Harvard College, above, paras 111-112. 
According to Rothstein JA those requirements derive from the definition of invention in section 2 of the Patent Act, as well as section 28.3 that provides the subject-matter of the patent must not have been obvious to persons skilled in the art or science. ${ }^{84}$ Section 2 of the Canadian Patent Act provides: "'invention' means any new and useful art, process, machine, manufacture or composition of matter, or any new and useful improvement in any art, process, machine, manufacture or composition of matter".

The "oncomouse" was new, useful, and unobvious, the Court of Appeal decided. It was not an art, process, or machine but did fall within the scope of the term "composition of matter". ${ }^{85}$ Whether or not it could also be a manufacture was not finally determined. ${ }^{86}$

In support of its decision to define a non-human mammal as a "composition of matter", the Court advanced the following reasons:

- A core concept of patent law is that inventions are "unanticipated and unforeseeable". ${ }^{87}$ The courts should therefore honour Parliament's intention, as evidenced by the broad and general language used, that the Patent Act should be interpreted expansively rather than restricted in scope. In other words: ${ }^{88}$

[T] he doctrine of contemporanea expositio - that the meaning of words in an enactment will be understood in the sense which they bore when the enactment was passed ... does not apply to the definition of 'invention' in the Patent Act.

- The fertilized mouse egg injected with the oncogene, the resulting founder mouse, and its offspring - at least those that carried the oncogene - fall within the definition of "composition of matter" used in Diamond $v$ Chakrabarty ${ }^{89}$ to include "all compositions of two or more substances and ... all composite articles, whether they be the results of chemical union, or of mechanical mixture, or whether they be gases, fluids, powders, or solids". ${ }^{90}$ This is because the fertilized mouse egg injected with the oncogene is biological matter combined with physical substance (DNA). It continues to be a "composition of matter", as it

84 President and Fellows of Harvard College, above, para 113.

85 President and Fellows of Harvard College, above, para 114

86 President and Fellows of Harvard College, above.

87 President and Fellows of Harvard College, above, para 142.

88 President and Fellows of Harvard College, above, paras 188-189.

89 Diamond v Chakrabarty (1980) 447 US 303.

90 Quoted in President and Fellows of Harvard College, above, para 115. 
develops to term in the host mouse. Offspring oncomice are also compositions of matter by virtue of the oncogene they carry. ${ }^{91}$

- $\quad$ Living things are not excluded from the definition "composition of matter".92

The Court therefore concluded: "[T]he Patent Act does not exclude living organisms, [that is], non-human mammals from the definition of 'invention'".93

To a possible objection that the "oncomouse" could not be an invention but was instead a discovery because its production followed the laws of nature - in its gestation within a host mouse and in its reproduction by natural means as an offspring oncomouse Rothstein JA responds: "[T]he use of the laws of nature by inventors does not disqualify a product from being an invention, provided inventiveness or ingenuity is also involved". ${ }^{94}$ In the case of the "oncomouse", ingenuity is involved at a molecular level with the assembly of the oncogene and at a cellular level by "incorporating it into the plasmid and injecting the plasmid into the zygote". .95

In effect, according to Mark Perry and Priti Krishna: ${ }^{96}$

The Appeal Court is saying that there is no distinction between living and non-living inventions, at least as far as patent law is concerned. The argument is that the creator of the modified gene is to be given a patent on the whole animal as it is made up of these genes.

To assess the possible impact of this decision in New Zealand with respect to the patenting of human beings, it is necessary to look at the law as it currently stands.

\section{Implications for New Zealand}

The requirements for patentability, it can be argued, are much the same in New Zealand as in Canada and therefore, the approach in President and Fellows of Harvard College $v$ Canada (Commissioner of Patents) might well be followed by New Zealand Courts to allow patenting of higher life forms - given that in our Act too, there is no express prohibition on the patenting of biotechnological inventions.

91 President and Fellows of Harvard College, above, paras 121-122.

92 President and Fellows of Harvard College, above, para 123.

93 President and Fellows of Harvard College, above.

94 President and Fellows of Harvard College, above, para 129.

95 President and Fellows of Harvard College, above.

96 Mark Perry and Priti Krishna "Making Sense of Mouse Tales" (2001) 23 EIPR 196, 202. 
The language of section 2's definition in New Zealand's Patents Act 1953 is similarly broad: "any manner of new manufacture", "any new method or process" indicating an expansive approach to its interpretation is also appropriate.

A particular genetically engineered mammal in New Zealand would also be new, useful, and unobvious, as the "oncomouse" was found to be in Canada.

Admittedly there are points of difference, the major one being the omission of the term "composition of matter" from section 2 of the New Zealand Act. Instead, the invention must be a "manner of new manufacture the subject of letters patent and grant of privilege within section 6 of the Statute of Monopolies".

Whether this is a sufficient obstacle to extending the categories of patentable subjectmatter is debatable. First, it should be noted that the Canadian Court did not rule out the possibility that the "oncomouse", as well as being a "composition of matter", might also be a "manner of manufacture". Secondly, New Zealand case law suggests it is an obstacle that might well be overcome.

\section{$3 \quad$ Wellcome Foundation v Patents Commissioner}

The case of Wellcome Foundation v Patents Commissioner ${ }^{97}$ concerned a claim for treating meningeal leukemia or neoplasms in the brain by use of a compound that had previously been used to treat malaria.

The question to be addressed by the Court of Appeal was whether a patent could be granted in New Zealand for a method of treatment of disease or illness in human beings. The Assistant Commissioner of Patents had refused to grant a patent on the grounds that the claim did not constitute a "manner of new manufacture".

The Court began by considering section 6 of the Statute of Monopolies 1623 which is incorporated into New Zealand patent law by means of the definition of invention in the Act. ${ }^{98}$ The Statute prohibits monopolies but for the following exception: 99

Provided also, and be it declared and enacted, that any declaration before mentioned shall not extend to any letters patents and grants of privilege for the term of 14 years or under, hereafter to be made, of the sole working or making of any manner of new manufactures within this Realm, to the true and first inventor and inventors of such manufactures, which others at the time of making such letters patents and grants shall not use, so as also they be not contrary to

97 Wellcome Foundation v Patents Commissioner [1983] 3 NZLR 385 (CA).

98 Patents Act 1953, s 2.

99 Statute of Monopolies 1623, s 6. 
the law or mischievous to the State, by raising prices of commodities at home or hurt of trade, or generally inconvenient ...

According to Justice Cooke (as he then was): ${ }^{100}$

"Manner of new manufacture" is an expression having no ordinary meaning today. It is commonplace that the scope of the idea can only be ascertained by seeing how far the law has evolved in the decided cases, and that trend has been to broaden the scope gradually.

Consequently, the Court approved the landmark decision of the High Court of Australia in National Research Development Corporation's Application (NRDC), ${ }^{101}$ which held with respect to the equivalent section in the Australian Patents Act: ${ }^{102}$

The word "manufacture" finds a place in the present Act, not as a word intended to reduce a question of patentability to a question of verbal interpretation, but simply as the general title found in the Statute of Monopolies for the whole category under which all grants of patents which may be made in accordance with the developed principles of patent law are to be subsumed.

Cooke J agreed that a new use of a known product could ground an invention. ${ }^{103}$ Nonetheless, the law in New Zealand and elsewhere in the Commonwealth had not evolved as far as extending the definition of "manner of new manufacture" to a method of medical treatment of human beings - as Chief Justice Davison had held in the High Court. Patenting such methods was still prohibited.

Although "logically ... the approach could go so far" and admit the patentability of the second pharmaceutical use of a medicament, "special considerations [had] to be borne in mind". ${ }^{104}$ Determining patentability was not simply a matter of "shaping [principles] into an intellectually satisfying pattern"; 105 it also involved a "balancing exercise"106 as ethical matters along with economic ones were considered. As Somers J noted "[O]ne of the features of the Statute of Monopolies is the embargo on patents 'generallie inconvenient'. That concept still informs the law". ${ }^{107}$ In this instance, the Court agreed, it was for

100 Wellcome Foundation, above, 387, Cooke J.

101 National Research Development Corporation's Application [1961] 102 CLR 252 [NRDC].

102 NRDC, above, 269.

103 Wellcome Foundation, above, 388, Cooke J.

104 Wellcome Foundation, above.

105 Wellcome Foundation, above.

106 Wellcome Foundation, above, 389, Cooke J.

107 Wellcome Foundation, above, 404, Somers J. 
Parliament to decide whether the prohibition on methods of medical treatment of human beings should be lifted. ${ }^{108}$

If this approach is followed in claims concerning genetically modified mammals including human beings - then it is not inevitable, nor even likely in some cases, that patents will be granted for them. However, the New Zealand Court of Appeal in a subsequent case of judicial review, Pharmaceutical Management Agency $v$ Commissioner of Patents (Pharmac), ${ }^{109}$ adopted a different, strictly logical analysis that ignored any "special considerations".

4 Pharmaceutical Management Agency v Commissioner of Patents

In Pharmac, the Court allowed that the discovery of a new pharmaceutical use for compounds already known to be effective in the treatment of one or more medical conditions could be recognised as an invention. Yet the Court also claimed that it had not decided that the patenting of methods of medical treatment of humans should be allowed. ${ }^{110}$ If lifting the prohibition on the patenting of such methods had been at issue, it might have been necessary to consider economic, ethical, and social matters. ${ }^{111}$ However, the Court was addressing the narrower question of whether or not the discovery of a further pharmaceutical use was an invention, and all that entailed was "an interpretation of the novelty requirement in the light of developments internationally". 112 By permitting "Swiss claims" - purpose-limited use claims, whereby patentees are given the right to use active chemicals to manufacture a drug for a new treatment purpose - the Court allowed that the novelty requirement for an invention was satisfied while the prohibition on the patenting of methods of medical treatments of human beings was maintained.

Like the Canadian Court in President and Fellows of Harvard College, Justice Gault in Pharmac purports merely to be conducting an exercise in statutory interpretation, having "distilled" the issue. ${ }^{113}$ However, in reaching the decision to allow "Swiss claims", the Court of Appeal has done more than refine the issue: It has re-characterised the inquiry that must be conducted to determine whether or not something is an invention in terms of the Act.

108 Wellcome Foundation, above.

109 Pharmaceutical Management Agency $v$ Commissioner of Patents [2000] 2 NZLR 529 (CA).

110 Pharmac, above.

111 Pharmac, above.

112 Pharmac, above.

113 Pharmac, above. 
The starting point for this inquiry - as it was for the Court in Wellcome - is section 6 of the Statute of Monopolies. The next step is to acknowledge that the concept of "manner of new manufactures" has been "flexibly and more broadly construed [by the Courts] ... to accommodate innovation in new fields of technology". 114 This means, in effect, that the subject matter of a claim should be deemed to be an invention if it follows logically from previous judicial decisions. Thus, in Pharmac, Justice Gault asserted that the NRDC decision "undermined what had been the major reason for the exclusion of patentability of methods of treating human beings - that they did not constitute inventions". 115

What is not necessary in determining whether something is an invention, after Pharmac, is the kind of balancing exercise that the New Zealand Court of Appeal in Wellcome referred to. Justice Gault does not deliberate on social and economic matters. Concerning section 6 of the Statute of Monopolies, he writes: "[I]t is not clear how much of the proviso (if anything) beyond the term 'manner of new manufactures' as construed in its context is incorporated into our statutory definition of 'invention'". ${ }^{116}$ In particular, the incorporation of the exceptions within the proviso (for example, the exclusion of inventions which are "generallie inconvenient") is questionable. ${ }^{117}$

Returning to the issue at hand, His Honour concludes: ${ }^{118}$

What emerges from this is that it no longer can be said that a method of treating humans cannot be an invention ... The exclusion from patentability of methods of medical treatment rests on policy (moral) grounds.

If the discretion for the Patent Commissioner to refuse a grant on moral grounds derives solely from section 17 and that section is repealed, then the way is clear in New Zealand for the patenting of higher organisms including human beings.

It might be argued that the general prohibition on the patenting of methods of medical treatment still exists, and that this represents an impediment to patenting genetically engineered human beings. The decision in Pharmac, so the argument might go, is confined to the drug manufacturing process. Yet the genetically engineered human organism is best regarded - like the 'oncomouse' - not as a method of medical treatment, but a consequence of it. The prohibition on patenting methods of medical treatment is not directly relevant.

114 Pharmac, above, 536, Gault J.

115 Pharmac, above, 536-537, Gault J.

116 Pharmac, above, 535, Gault J.

117 Pharmac, above, 538, Gault J.

118 Pharmac, above. 


\section{INTERNATIONAL OBLIGATIONS}

As a member of the World Trade Organisation (WTO), New Zealand must comply with the provisions of the agreement on Trade-Related Aspects of Intellectual Property Rights (TRIPs), ${ }^{119}$ the most comprehensive, multilateral agreement on intellectual property to date.

Article 1.1 states that the standards of protection set out in the agreement are obligatory but minimum standards: "Members may ... implement in their law more extensive protection than is required by this Agreement". The scope of patentable subject matter is outlined in Article 27.1 which makes clear that member nations must make patents available for biotechnological innovations provided the usual tests of patentability are met: ${ }^{120}$

Subject to the provisions of paragraphs 2 and 3, patents shall be available for any inventions, whether products or processes, in all fields of technology, provided that they are new, involve an inventive step and are capable of industrial application.

Three exceptions are permitted by TRIPs. The first contained in Article 27.2 includes inventions that, if commercially exploited, would be contrary to "ordre public" or morality. "Ordre public" is not defined, though Philip Grubb suggests that under German law "it would mean a violation of a basic constitutional right such as the right to life, personal freedom, human dignity, and freedom from bodily harm. Ordre public means the proper order of society". ${ }^{121}$ Particular mention is made in Article 27.2 of the necessity of protecting human, animal or plant life, or health, and avoiding serious environmental risk.

Other permitted exceptions to patentability are provided in Article 27.3(a): diagnostic, therapeutic, and surgical methods for the treatment of humans or animals; and in Article 27.3(b): plants and animals other than micro-organisms, and essentially biological processes for the production of plants or animals other than non-biological and microbiological processes.

Adopting a narrow interpretation of the term human being displays adherence to Article 27.1 of TRIPs. By extending patentability to inventions incorporating human

119 Trade Related Aspects of Intellectual Property Rights Agreement (Annex 1C, World Trade Organisation, Marrakesh Agreement) signed 15 April 1994 and came into effect 1 January 1995 [TRIPs].

120 According to Note 5 "For the purposes of this Article, the terms 'inventive step' and 'capable of industrial application' may be deemed by a Member to be synonymous with the terms 'nonobvious' and 'useful' respectively".

121 Philip W Grubb Patents for Chemicals, Pharmaceuticals and Biotechnology (Clarendon Press, Oxford, 1999) 256. 
biological material, the Act will ensure that patent protection is available in all fields of technology. Furthermore the prohibition on patenting human beings as whole (if genetically modified) organisms falls within the permitted exception contained in Article 27.2 , as being contrary to morality or "ordre public". Human dignity and personal freedom are safeguarded.

In its submission to the Royal Commission on Genetic Engineering, the New Zealand Institute of Patent Attorneys (NZIPA) indicated that regard should be had not only to our international treaty obligations, but also to the practice of other jurisdictions. ${ }^{122}$ It is instructive to look at the European approach to this issue before evaluating the NZIPA's Attorney's formulation for an excluding provision.

\section{EUROPEAN PATENT LAW}

\section{A Directive 98/44/EC of the European Parliament and of the Council of 6 July 1998 on the Legal Protection of Biotechnological Inventions}

The European Union (EU) Directive on the legal protection of biotechnological inventions was approved by the European Parliament in 1998 in an attempt to harmonise the national laws of EU member states which, according to Recital 3, was essential to maintain and encourage investment in the field of biotechnology.

Chapter 1 of the Directive is concerned with patentability, Article 1 states that: "Member States shall protect biotechnological inventions". The requirements for patentability - novelty, inventive step, and susceptibility to industrial application - are set out in Article 3 which states that inventions that meet these criteria shall be patentable "even if they concern a product consisting of or containing biological material" or a process which involves such material.

Reference to humans and human material is expressly made in Article 5:

(1) The human body, at the various stages of its formation and development, and the simple discovery of one of its elements, including the sequence or partial sequence of a gene, cannot constitute patentable inventions.

(2) An element isolated from the human body or otherwise produced by means of a technical process, including the sequence or partial sequence of a gene, may constitute a patentable invention, even if the structure of that element is identical to that of a natural element.

122 NZIPA Patenting of Biotechnologies Inventions (submission to Royal Commission on Genetic Modification, 2001) 7. 
(3) The industrial application of a sequence or a partial sequence of a gene must be disclosed in the patent specification.

Read in the light of Recital 16, Article 5(1) can be seen as respecting "the fundamental principles safeguarding the dignity and integrity of the person". It "asserts the principle that the human body, at any stage in its formation or development, cannot be patented". These principles, according to Recital 16, "are in line with the criteria of patentability proper to patent law, whereby a mere discovery cannot be patented".

It is arguable whether or not these principles are always "in line with" patentability criteria. Nonetheless, Article 5(1) read together with Article 5(2) could be interpreted as prohibiting - among other things - the patenting of a human being whose genome has been modified. A distinction is made, after all, between the whole organism (the body) and its elements, and it is only the elements that are deemed to be patentable when isolated. It could further be argued that this prohibition extends to genetically modified foetuses and embryos, given the reference to "the human body, at the various stages of its formation and development".

Article 5(3) specifically refers to sequences or partial sequences of a gene, stating that industrial application of the sequence must be disclosed. In order to comply with this requirement, according to Recital 24:

[I]t is necessary in cases where a sequence or partial sequence of a gene is used to produce a protein or part of a protein, to specify which protein or part of a protein is produced or what function it performs.

If the intention is not to allow the patenting of functionless sequences such as express sequence tags (ESTs), much still depends on how "industrial application" is interpreted, as Grubb points out. ${ }^{123}$ Whatever arguments are put forward for the patenting of ESTs, at least some will apply to SNPs that also function as markers along the genome.

Article 6 of the European Union Directive lays down a further prohibition on patentability based on the general ground of commercial exploitation of the invention being "contrary to ordre public or morality". Of particular concern to the European Parliament are processes for cloning human beings and processes for modifying the germ line genetic identity of human beings, which are mentioned in Recitals 40 and 41 and expressly excluded in Article 6(2)(a) and (b). Also excluded are uses of human embryos for industrial or commercial purposes. Such exclusion, according to Recital 42, "does not effect inventions for therapeutic or diagnostic purposes which are applied to the human embryo and are useful to it". 
Finally, Article 6(2)(d) expressly prohibits "processes for modifying the genetic identity of animals which are likely to cause them suffering without any substantial medical benefit". It would seem to follow from this that transgenic animals carrying copies of human genes are patentable, as long as the condition related to suffering is met.

The list of exclusions in Article 6(2) is not exhaustive, and is merely illustrative according to Recital 38. Obviously, also excluded are inventions offensive to human dignity. In light of the unspecified scope of the morality exclusion, it is just as well that Article 7 provides that "the Commission's European Group on Ethics in Science and New Technologies evaluates all ethical aspects of biotechnology".

\section{B The European Patent Convention (EPC)}

The European Patent Convention (EPC) established the European Patent Organisation comprising the European Patent Office (EPO) and the Administrative Council. ${ }^{124}$ The Convention is adhered to by all the members of the European Union. It to requires that an invention be new, involve an inventive step, and be capable of industrial application to be patentable. $^{125}$

Article 53(a) of the EPC prohibits the grant of European patents for inventions the publication or exploitation of which would be contrary to (a) 'ordre public' or (b) morality irrespective of whether or not the invention is patentable under Article 52.

The EPO, however, is not an instrument of the European Union and, until recently, the EU Directive on the legal protection of biotechnological inventions was not directly applicable to its decisions. ${ }^{126}$ However, the Directive has now been incorporated into the Implementing Regulations of the EPC. "Its implementation by the Administrative Council", declared the President of the EPO in June 2000, "is an expression of the political will of the Organisation and the Office to respect the principles laid down by the European legislator and to incorporate them in the European Patent Convention". 127

\section{AN ANALYSIS OF THE RECOMMENDATION OF THE NZIPA AS ADOPTED BY THE ROYAL COMMISSION ON GENETIC MODIFICATION}

In its submission to the Royal Commission on Genetic Modification (the Royal Commission), the NZIPA recommended that section 17 of the Act "be repealed and that a

124 Grubb, above, 27.

125 Grubb, above, 53.

126 Grubb, above, 254.

$127 \mathrm{Mr}$ Inger Kober, President of the EPO (Address to the annual press conference of the EPO, Munich, 26 June 2000). 
new provision should be added to exclude humans from patentability, based on the equivalent section in the Australian Patents Act 1990.128

In its Report, the Royal Commission noted but did not adopt the suggestion that section 17 be removed, instead suggesting the establishment of Toi te Taiao: The Bioethics Council. ${ }^{129}$ It did, however, adopt without modification the NZIPA's recommendation concerning a new provision advising Government: ${ }^{130}$

[T] hat the Patents Act 1953 be amended by adding a specific exclusion of the patentability of human beings and the biological processes for their generation, in line with section 18 of the

Patents Act 1990 (Commonwealth).

Consequently, an analysis of NZIPA's recommendation devolves to some extent into an analysis of the Royal Commission's formulation of the amendment.

It is arguable that the precise scope of the proposed amendment is not clear, even though a commentary of sorts is provided in the section on "Patenting of humans" 131 in the Report. Reference can also be made to the practice of the Australian Patent Office in interpreting section 18 of the Australian Act.

As noted above, the Royal Commission suggests that the amendment does nothing more than maintain the status quo. Nonetheless, it is desirable "to put the issue beyond doubt", the issue being whether a "patent covering human beings would be granted". The amendment, it believes, merely serves to strengthen current prohibitions.

Two parts of the legislation referred to by the Commission in support of this belief are sections 2 - the definition of invention - and 10(7) of the Patents Act. It characterises both sections as preventing the patenting of things found in nature. ${ }^{132}$ If reference was made to these two sections alone, then it could be stated that the Commission intends the amendment only to cover human beings as whole - "unmodified" - organisms from birth onwards. It could also be stated with some certainty that the phrase "the biological processes for their generation", which is taken directly from the Australian Act, might be

128 NZIPA "Patenting of Biotechnological Inventions" (submission to Royal Commission on Genetic Modification, 2001) 10.

129 Royal Commission on Genetic Modification Report of the Royal Commission on Genetic Modification (Wellington, 2001) 281.

130 Royal Commission on Genetic Modification, above, 285.

131 Royal Commission on Genetic Modification, above, 284.

132 Royal Commission on Genetic Modification, above. 
interpreted along the lines of the Australian Patent Office to cover, at the very least, claims to unmodified foetuses, embryos, and fertilised eggs. ${ }^{133}$

However, the Commission also refers to the morality section of the Act, section 17, which is "the basis for IPONZ's [the Intellectual Property Office of New Zealand] policy to refuse patents for humans" and then goes on to state: "Taken together, these patent criteria ought to mean that a patent cannot be obtained over a human, a human body part, or a human gene in its natural host, a human". ${ }^{134}$ The term human is not defined, but this sentence read with the following one suggests that the Commission means to extend the prohibition on patenting to cover human organisms whose genomes have been genetically engineered: ${ }^{135}$

At best a patent could be granted for a synthetic DNA molecule carrying the same information as found in the human body, or a method for producing a novel human organ or body part suitable for transplantation.

Using the Report as an interpretative aid, it is clear that according to the Royal Commission isolated DNA molecules fall within the scope of patentable subject matter. The effect of extending the prohibition to the "biological processes for their generation" in the proposed amendment is otherwise somewhat uncertain for at the heart of these processes are DNA sequences. It is still not certain how much further down the scale patenting is permitted, that is, how much smaller in size than a whole DNA molecule is permissable. Can isolated DNA sequences that comprise a gene, DNA sequences such as ESTs and SNPs (if they met the utility requirement), and proteins be patented? Moving up the scale in size from DNA molecules, does patentability extend to genetically engineered organs?

The Report states: ${ }^{136}$

It should be noted that the discovery of a method of producing a liver "in vitro", for example, would only give the patentee a right to exclude others from producing livers using this method. It gives no ownership rights to any person's liver. Consequently any public perception that "people are being patented" is a misconception of patent law.

If a patent can be granted on a "synthetic DNA molecule carrying the same information as found in the human body", can a patent not be granted on a synthetic liver - not just the

133 Quoted in Ministry of Commerce Patenting of Biotechnological Inventions: Discussion Paper (Wellington, 1999) 11.

134 Royal Commission on Genetic Modification, above.

135 Royal Commission on Genetic Modification, above.

136 Royal Commission on Genetic Modification, above. 
method for producing it? Once the liver has been transplanted then the prohibition on patenting human beings might come into play, but might the patentee not have some form of ownership up to that time?

Although the Royal Commission's commentary on the proposed amendment is confusing in places, it appears that the intention of the Report is to recommend that the patenting of human biological material be allowed but that the patenting of human beings, as whole organisms including embryos and foetuses, whether or not they have been genetically engineered, be prohibited. In effect, it adopts the narrowest definition of human being as an organism from birth but extends the ban to exclude the organism in its earlier stages of development.

It is justifiable to assume that the intended scope of the NZIPA's ammendment is identical to that of the Commission's, given that both recommendations are formulated in identical terms.

\section{CONCLUSION}

The effect of a provision excluding human beings from patentability depends on how the term human being is interpreted. There are powerful arguments for encouraging biotechnological inventions using human biological material, which suggests that New Zealand should adopt a narrow definition of the term. Despite a lack of clarity in its discussion of the issue, the Royal Commission on Genetic Modification appears to favour this definition, which would render unpatentable human organisms from birth and encompass individuals whose genome had been engineered in some way. How narrow the definition should be is a matter of debate. To be consistent with European patent law and Australian practice, though, the prohibition on patenting needs to cover human embryos and foetuses even if human being is interpreted as a whole organism from birth onwards.

The way in which the excluding provision is formulated needs to be carefully considered. Given the ambiguities of the recommended Australian formulation, it might be preferable to model the provision along the lines of Articles 5 and 6 of the European Union Directive on the legal protection of biotechnological inventions. Along with the associated Recitals, the Articles make apparent the distinction between naturally occurring elements that cannot be patented and isolated elements that can, between discovery and invention. By making much more explicit the requirement for disclosure of an industrial application, it goes some way to meeting the concerns of allowing the patenting of upstream research.

In the light of recent case law from Canada and New Zealand, a provision excluding human beings as whole organisms from patentability would do more than put the matter beyond doubt: Its inclusion is essential if section 17 is repealed. 
